\title{
Reducing the U.S. Deficit by Recycling Capital Inflows
}

Yi Wen, Vice President and Economist

$\mathrm{T}$ he United States has been running large and persistent trade deficits with other economies, especially emerging markets such as China, for decades. Persistent trade imbalances imply that the United States has been consuming more than it produces or, equivalently, saving less than it invests. This means that the United States has been borrowing heavily from foreigners (especially China) to finance its domestic investment.

Critics say that to rebalance its current account the United States needs to either increase its saving rate or lower its investment rate. Both approaches are painful for the U.S. economy and will lead to lower aggregate demand and hence slower economic recovery. However, the very nature of the trade deficit itself offers a solution.

A trade deficit in a country's current account is the same thing as a surplus in its capital account. For example, China's trade surplus with the United States must be balanced by its investment in U.S. assets (or by holding dollars as foreign reserves). This accounting identity suggests a solution for resolving the U.S.-China trade imbalance problem without lowering U.S. aggregate demand.

\section{The United States can simply recycle the financial capital inflows from China and re-export them back to China in the form of FDI. In so doing, the United States gains a substantially larger rate of return from FDI than China does from owning U.S. government bonds.}

Here is the underlying logic. First, we need to understand why China is willing to lend to the United States when it is still struggling with low consumption per capita. The answer is that Chinese households need to save for precautionary reasons but do not have good domestic investment opportunities for their savings. Hence, financial capital (demand for liquid financial assets) tends to flow abroad from China to more developed economies (especially the United States) because household savings in China cannot be channeled effectively to its production sector. In other words, private firms in China are not able to gain free access to household savings despite rapid productivity growth. So China's excessive saving rate is not matched by its domestic investment rate. This mismatch, in turn, implies that the rate of return to fixed capital in China's private production sector is significantly higher than it is in the United States.

Indeed, the real rate of return to fixed capital in China has exceeded 20 percent in the past two decades, while the real rate of return to financial capital (such as bank deposits and short-term bonds) has been negative. Despite such an enormous gap, households in China save excessively in the form of bank deposits, indicating severely underdeveloped financial markets within China. This lack of a sophisticated financial system has been driving China's household savings into the United States to seek safer and better returns (see Wang, Wen, and $\mathrm{Xu}, 2012$ ).

However, the enormous gap between returns to household savings and returns to fixed capital in China also offers a tremendous profit opportunity for U.S. investors, especially U.S. firms. Basically, the United States can simply recycle the financial capital inflows from China and reexport them back to China in the form of foreign direct investment (FDI). ${ }^{1}$ In so doing, the United States gains a substantially larger rate of return from FDI than China does from owning U.S. government bonds.

FDI outflows from the United States to China can offset China's massive financial capital flows into the United States and help rebalance America's large trade deficit with China. In other words, American firms can reinvest China's cheap financial capital inflows (household savings) back in China in the form of FDI to earn higher rates of return than the Chinese do by holding U.S. Treasury notes. Namely, the United States receives (borrows) cheap savings from the Chinese, and U.S. firms use those savings to set up new firms or buy existing firms in China. Given China's high rate of return to capital in its production sec- 
tor, American firms can gain significantly more in such a two-way capital flow process than the Chinese savers could. From the viewpoint of the current account, this process of capital recycling amounts to letting the Chinese produce labor-intensive consumption goods for the United States and Americans produce capital goods for China, which uses both countries' comparative advantages and is thus a win-win solution for trade imbalances between the two nations.

Therefore, rebalancing its trade deficit with China does not mean American consumers need to tighten their belts or American firms need to lower their domestic investment rate. Instead, the U.S. government can encourage U.S. firms to produce more capital goods and send them to China in the form of FDI, which has been strongly favored by the Chinese markets. This approach will also increase U.S. employment in the manufacturing sector. Ironically, the current U.S. policy in practice discourages American FDI outflows to China rather than encourages them, as the government fears technology transfers and losses of domestic employment. For example, in 2010 the total accumulated FDI outflows from the United States to China and other less developed countries accounted for just 5 percent of U.S. gross domestic product, whereas the total financial capital inflows into the United States from China and other less developed countries accounted for more than 25 percent. This imbalance of two-way capital flows and policy orientation toward American FDI outflows have exacerbated the U.S.-China trade imbalance problem.

\section{Note}

${ }^{1} \mathrm{FDI}$ is investment directly into production in a foreign country by a domestic firm, either by buying a company in the foreign country or by expanding operations of an existing business in that country. So FDI implies sending capital equipment to foreign countries.

\section{Reference}

Wang, Pengfei; Wen, Yi and Xu, Zhiwei. "Two-Way Capital Flows and Global Trade Imbalances: A Neoclassical Approach.” Working Paper No. 2012-016A, Federal Reserve Bank of St. Louis, June 2012, http://research.stlouisfed.org/wp/2012/2012-016.pdf. 